\title{
A hypothesis on biological protection from space radiation through the use of new therapeutic gases as medical counter measures
}

\author{
Michael P Schoenfeld ${ }^{1 *}$, Rafat R Ansari ${ }^{2}$, Atsunori Nakao ${ }^{3}$ and David Wink ${ }^{4 *}$
}

\begin{abstract}
Radiation exposure to astronauts could be a significant obstacle for long duration manned space exploration because of current uncertainties regarding the extent of biological effects. Furthermore, concepts for protective shielding also pose a technically challenging issue due to the nature of cosmic radiation and current mass and power constraints with modern exploration technology. The concern regarding exposure to cosmic radiation is biological damage that is associated with increased oxidative stress. It is therefore important and would be enabling to mitigate and/or prevent oxidative stress prior to the development of clinical symptoms and disease. This paper hypothesizes a "systems biology" approach in which a combination of chemical and biological mitigation techniques are used conjunctively. It proposes using new, therapeutic, medical gases as chemical radioprotectors for radical scavenging and as biological signaling molecules for management of the body's response to exposure. From reviewing radiochemistry of water, biological effects of $\mathrm{CO}, \mathrm{H}_{2}, \mathrm{NO}$, and $\mathrm{H}_{2} \mathrm{~S}$ gas, and mechanisms of radiation biology, it can be concluded that this approach may have therapeutic potential for radiation exposure. Furthermore, it also appears to have similar potential for curtailing the pathogenesis of other diseases in which oxidative stress has been implicated including cardiovascular disease, cancer, chronic inflammatory disease, hypertension, ischemia/reperfusion (IR) injury, acute respiratory distress syndrome, Parkinson's and Alzheimer's disease, cataracts, and aging. We envision applying these therapies through inhalation of gas mixtures or ingestion of water with dissolved gases.
\end{abstract}

Keywords: space radiation, radiolysis, radiochemistry, radiation shielding, therapeutic medical gas, reactive oxygen species, oxidative stress, countermeasure

\section{The Challenge of Space Radiation}

Galactic Cosmic Rays (GCR), solar energetic particles (SEP), and trapped energetic particles in a planetary magnetic field are natural sources of radiation in space. GCRs consist of highly energetic nuclei, predominately protons and $\mathrm{He}$, but also trace amounts of $\mathrm{C}, \mathrm{O}, \mathrm{Ne}, \mathrm{Si}$, $\mathrm{Ca}$, and $\mathrm{Fe}$ ions. Particle energies can range from 100 $\mathrm{MeV}$ to $10 \mathrm{GeV}$ per nucleon [1]. Although the high charge and energy (HZE) nuclei are in trace amounts, they are still of concern because they can cause more damage than protons since they are more highly

\footnotetext{
* Correspondence: michael.p.schoenfeld@nasa.gov; wink@mail.nih.gov ${ }^{1}$ National Aeronautics and Space Administration Marshall Space Flight Center, Huntsville, Alabama, USA

${ }^{4}$ National Institute of Health, National Cancer Institute, Radiation Biology Branch, Bethesda, Maryland, USA

Full list of author information is available at the end of the article
}

ionizing. As well, even though particle fluxes are typically low, they are chronic and can significantly increase with solar events [1]. Furthermore, GCRs and SEPs impinging on shielding material, atmosphere, or surface of a planet or satellite can produce secondary radiation, including energetic neutrons, from nuclear fragmentation of the primary ion and target atoms. This can introduce an additional component to the radiation field which makes shielding from HZE quite challenging and poses one of the principal unknowns in understanding the HZE effects with human tissue [2]. Furthermore, while our bodies do possess a natural repair mechanism, radiation with a high linear energy transfer (LET) rate, like space radiation, is attributed to be more likely to cause double strand breaks in DNA that are relatively more difficult for our natural repair mechanisms to fix

\section{Biomed Central}


correctly [3]. While a week or month of this radiation at the dose rates naturally present likely will not have serious consequences, several year durations in space could. The traditional paradigm for radiation protection is to minimize exposure time, maximize distance from radiation sources, and use shielding to attenuate and absorb radiation before it can deposit its energy in humans. In regards to minimizing exposure time, new propulsive technologies could reduce trip times but have yet to be developed and would not address the ability to remain at a location for long durations. It is impractical to maximize distance from cosmic radiation sources. In regards to shielding, aspects of attenuation by mass or deflection by magnetic fields or charge repulsion have been considered. Due to the phenomena of secondary radiation, shielding by other matter may require a significant amount of mass which could be impractical within current mass constraints in space systems. Due to the high energy of the space radiation, magnetic field and charge strengths required for deflection may be currently impractical because of mass and power constraints in modern space systems along with other system design implications. In short, shielding space radiation is seemingly quite challenging. However, advances in biochemistry may reveal some more tools for radiation protection [2].

\section{Parallels between Radiation Chemistry of Water \& Radiobiology}

Radiolysis is the decomposition of water from exposure to ionizing radiation. Radiation chemistry of water has been well studied since the onset of nuclear power production, as water has been the most often used coolant. Since mammalian cells are composed of about $80 \%$ water, it seemed natural that there exist similarities between radiation chemistry of water and radiation biology. It is these similarities from which analogues for radioprotective measures were inspired.

\section{Chain of Events Initiated by Chemically Reactive Species}

Radiolysis in nuclear systems causes a chain of events that ultimately manifest into systematic problems like corrosion and gas generation. Ionizing radiation creates chemically reactive radicals $\mathrm{H}_{3} \mathrm{O}^{+}, \mathrm{e}^{-}, \mathrm{H}^{+}, \mathrm{H}$, and $\mathrm{OH}$ by ionizing and/or breaking the bonds of water molecules. These radicals then initiate a chain of chemical reactions within the water which can result in the formation of molecular decomposition products such as $\mathrm{H}_{2}, \mathrm{O}_{2}, \mathrm{HO}_{2}$ and $\mathrm{H}_{2} \mathrm{O}_{2}$. BWR recirculation water contains oxygen and hydrogen peroxide in the concentration range from 100 to $300 \mathrm{ppb}$, and about $10 \mathrm{ppb}$ of dissolved hydrogen (less than stoichiometric ratio of 8 to 1) [4]. These oxidizing species alter the water composition and therefore its electrochemical character which facilitates the manifestation of problems like corrosion or gas generation. As such, the nature in which systematic problems develop can be viewed as stemming from a chain of events that are initiated by ionization and propagated by a scheme of chemical reactions with the net result or outcome depending upon the ensuing chemistry.

This scenario is similar in nature to a biological system and the pathogenesis of radiation related ailments and disease. Ionization of key biological molecules can lead to chemical reactions which transform these molecules. This alters their biochemical function and can result in changes of their biochemical properties. Modification of biochemical properties propagates from a cellular level to organ and systematic changes that ultimately manifest into clinical symptoms and ailments. Ionization of the molecules can be initiated both directly (by radiation) and indirectly (by free radicals and reactive oxygen species (ROS) created by radiolysis). Free radicals and ROS like $\mathrm{O}_{2}{ }^{-},{ }^{1} \mathrm{O}_{2}, \cdot \mathrm{OH}, \cdot \mathrm{OOH}, \mathrm{NO} \cdot$ and $\mathrm{H}_{2} \mathrm{O}_{2}$ can cause cell injury or death by oxidative stress $[5,6]$. Oxidative stress to the cell results from such things as DNA damage or lipid peroxidation. Disease can then develop as a direct result of radiation damage or due to a system impairment caused by radiation damage such as the case of radiation-induced damage of chromosomes in lymphocytes compromising the immune system's ability to prevent tumor development [7]. Overall, the greatest risks from radiation exposure are assumed to be cancer [8], cataracts, and damage to the central nervous system [9]. Thus the nature of the problem seems similar to nuclear systems in that systematic manifestations result from a chain of events initiated by ionization and propagated, in this case, by ensuing chemical reactions and biological responses.

Interestingly enough, oxidative stress has been implicated to play a role in the development of other diseases as well $[10,11]$. That is, the normal production and development of a variety of disorders and diseases has also been associated with an increase of oxidative stress and inflammation similar to that which would be caused by exposure to radiation. For example, certain detrimental effects from space radiation on the dopaminergic system are similar to functional changes that occur from Parkinson's disease [9], diabetogenic problems associated with increased $\mathrm{C}$-peptide excretion and insulin resistance [12], as well as constipation due to malfunction of the intestine. Oxidative stress during space flight can cause a loss of protein after reductive remodeling of skeletal muscle due to undernutrition [13]. Diseases in which oxidative stress is implicated, and thus which could also be affected by the countermeasures proposed in this paper, include cardiovascular disease, cancer [14], chronic inflammatory disease [15], hypertension [16], ischemia/reperfusion injury [5], acute respiratory distress 
syndrome (ARDS) [17], neurodegenerative diseases such as Parkinson's disease and Alzheimer's disease $[18,19]$ and aging [20].

\section{Radical Scavenging \& Antioxidants}

The actual chemical reactions that ensue and their byproducts depend upon what the radicals come into contact with. For example, in pure water, radical-radical interactions lead to the formation of the decomposition products while radical-decomposition product reactions lead to the reformation of water. In a nuclear system, manifestation of system level problems has been curtailed by interfering with the chain of events early on during the chemical stages through the use of additives that alter water composition. Whereas some additives have been found to promote and increase water decomposition, others have been found to suppress it [21]. This occurs through scavenging in which the additives preferentially react with the radicals. Scavenging has the effect of removing reactive species from the system and thereby reduces their ability to participate in chemical reactions that cause decomposition. While there are various additives that preferentially react with decomposition products, the byproducts of the scavenging reaction are a factor as well since they are a component of the water composition. For example, some ionic impurities scavenge radicals (shown in 1-4) but do so at the expense of water reformation as the consumed $\mathrm{H}$ and $\mathrm{OH}$ radicals are no longer available to react with decomposition products in the reactions that lead to water reformation.

$$
\begin{aligned}
& \mathrm{OH}+\mathrm{Br}^{-} \rightarrow \mathrm{Br}+\mathrm{OH}^{-} \\
& \mathrm{H}+\mathrm{Br} \rightarrow \mathrm{Br}^{-}+\mathrm{H}^{+} \\
& \mathrm{H}+\mathrm{Cu}^{++} \rightarrow \mathrm{Br}^{-}+\mathrm{H}^{+} \\
& \mathrm{OH}+\mathrm{Cu}^{+} \rightarrow \mathrm{Cu}^{++}+\mathrm{OH}^{-}
\end{aligned}
$$

However, the use of excess $\mathrm{H}_{2}$ in a water system exposed to radiation provides the initial $\mathrm{H}$ radicals for a chain reaction that promotes water reformation and in which there is no net consumption of $\mathrm{H}_{2}$ in the process (shown in 5-6).

$$
\begin{aligned}
& \mathrm{H}_{2}+\mathrm{OH} \rightarrow \mathrm{H}_{2} \mathrm{O}+\mathrm{H} \\
& \mathrm{H}+\mathrm{H}_{2} \mathrm{O}_{2} \rightarrow \mathrm{H}_{2} \mathrm{O}+\mathrm{OH}
\end{aligned}
$$

The ability of $\mathrm{H}_{2}$ to suppress total oxidant concentrations in a water system exposed to radiation has long been recognized by the boiling water reactor (BWR) community and is referred to as hydrogen water chemistry (HWC). The first full-scale HWC test in the U.S. was performed at Dresden-2 in 1982 and similar tests have subsequently been carried out in several reactors [4]. In the presence of excess $\mathrm{H}_{2}$, both the water decomposition and production of $\mathrm{O}_{2}$ can be suppressed through a chain reaction which rapidly reduces the concentration of $\mathrm{OH}$ and $\mathrm{H}_{2} \mathrm{O}_{2}$. In an accelerator application, Lillard et al. [22] has shown that this has the effect of suppressing the Open Circuit Potential (OCP) of the water (Figure 1) and thereby electrochemically reduces the driving potential for corrosion.

Similarly, in a biological system, antioxidants have been seen to protect against oxidative stress and prevent the pathological process of a wide range of disease [23]. The effect of antioxidants in reducing oxidative stress can be attributed to their ability to protect tissues from free radicals [6] hinting towards a scavenging mechanism. Turner [24] indicates, "A number of radiosensitizing chemicals and drugs are known. Some sensitize hypoxic cells, but have little or no effect on normally aerated cells. Other agents act as radioprotectors reducing biological effectiveness...which scavenge free radicals. Still other chemicals modifiers have little effect on cell killing but substantially enhance some multistep processes, such as oncogenic cell transformation." Thus it appears that antioxidants act similarly to radical scavengers in nuclear coolant systems in that they chemically protect against indirect ionization by preferentially reacting with the reactive species and thus reducing their ability to cause oxidative stress.

The dependency of the outcome on scavenger type is also similar to nuclear systems where the effect of the type of additive can either be to promote water

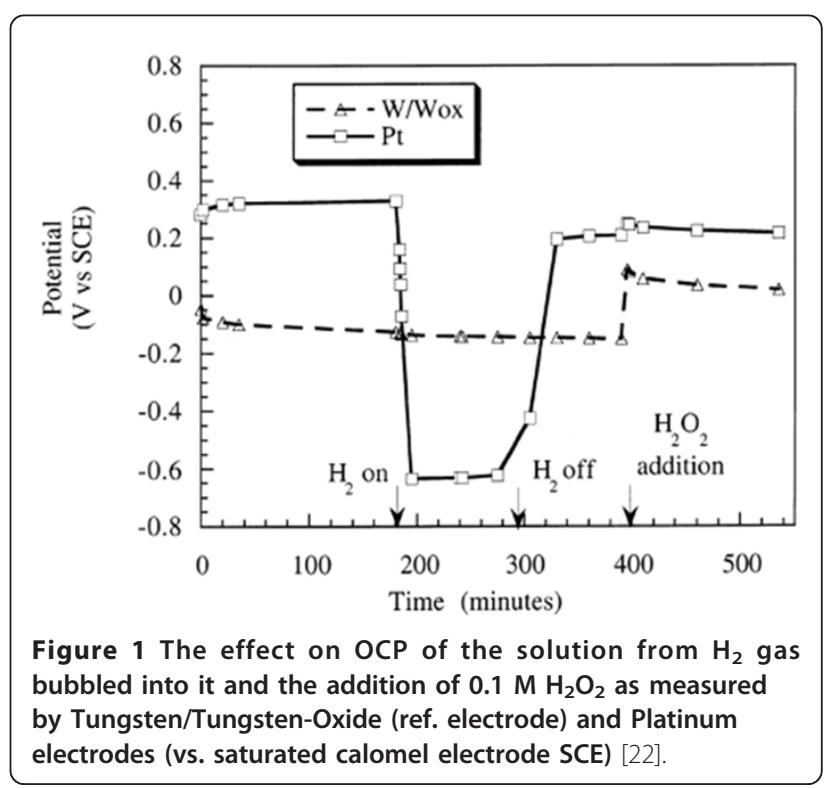




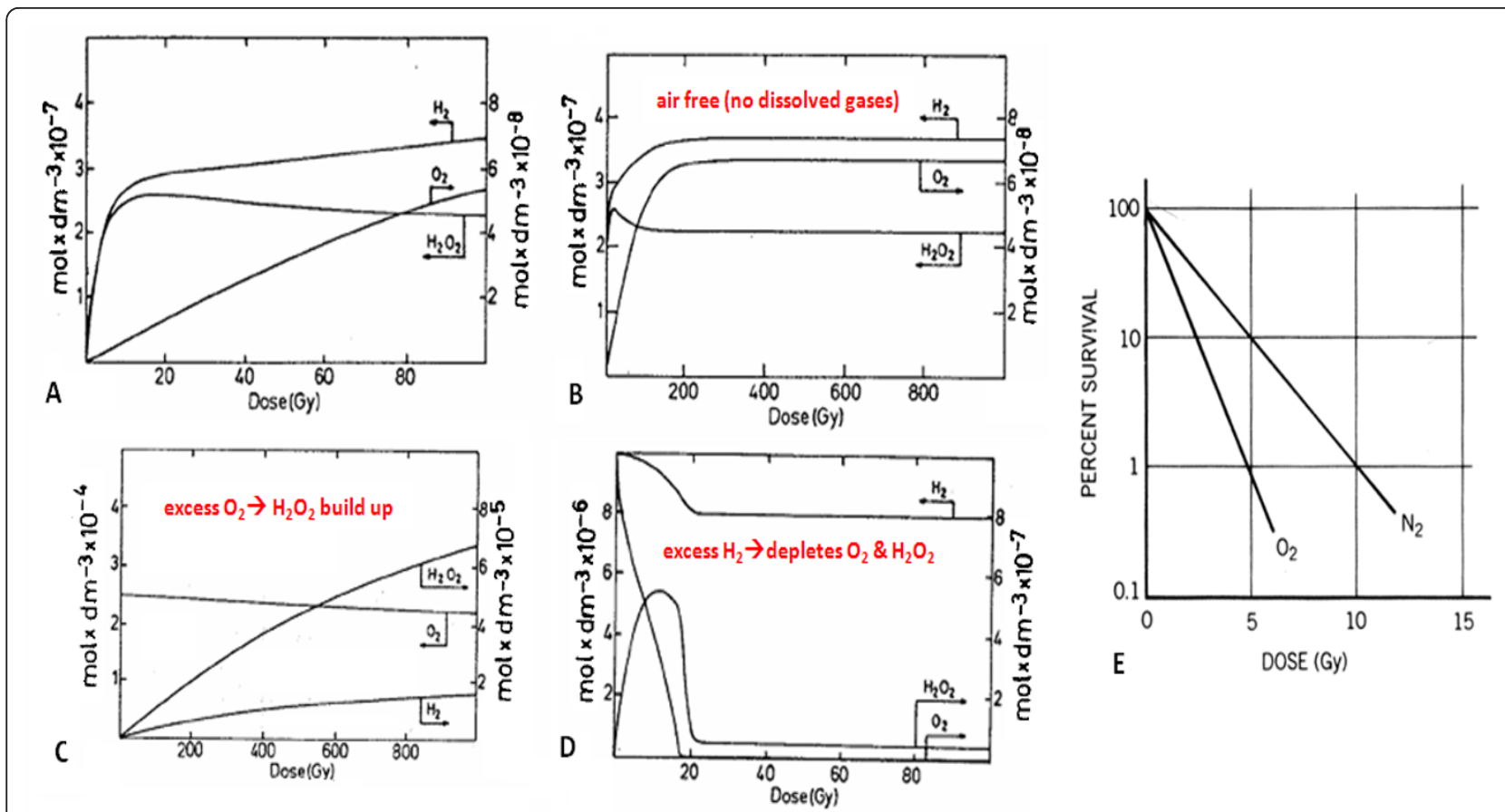

Figure 2 (A)-(D)[25]reflect water decomposition by the concentration of radiolysis byproducts. (B) is an extension of (A) and is air free pure water. Decomposition ensues until $\mathrm{H}_{2}$ in excess of ROS. (C) is effect of dissolved $\mathrm{O}_{2}$ in excess of $\mathrm{H}_{2}$ to promote decomposition. (D) is effect of dissolved hydrogen in excess of $\mathrm{O}_{2}$ to scavenge. (E) [24] Shows effect of $\mathrm{O}_{2}$ as a biological radiosensitizer. $\mathrm{N}_{2}$ is also shown which raises the question of what the effect of $\mathrm{H}_{2}$ would be.

decomposition or water reformation. One such example is the effect of oxygen. There appears to be parallels in the effect of oxygen to promote water decomposition in a nuclear system and increased radiosensitivity of cells in the presence of oxygen as shown in Figure 2C[25]. With increased water decomposition, it would be expected that there would be more ROS produced leading to increased damage. This is the case as cell survival decreases under oxic conditions when exposed to Xand $\gamma$-rays implying that the indirect effect of radiolysis byproducts are the most damaging to the cell. This oxygen effect is quantified by the oxygen enhancement ratio (OER) that reflects the relative increase of radiation dose needed to produce the same biological damage under hypoxic conditions as opposed to oxic conditions. Figure 2D[25] includes the effect of hydrogen on water decomposition and shows that when in excess of ROS like $\mathrm{O}_{2}$ and $\mathrm{H}_{2} \mathrm{O}_{2}$, the water reformation process dominates as ROS are quickly scavenged. This raises the question of what would the effect of $\mathrm{H}_{2}$ be on radiosensitivity of cells? Also noteworthy in Figure 2 is the occurrence of an equilibrium where the amount of molecular decomposition byproducts from radiolysis remains constant. This hints at a scenario of two competing processes in which a critical point occurs when a balance is achieved between water decomposition and reformation and suggests that radical scavengers can shift which process dominates. Biological parallels and implications of this are discussed next.

\section{A Scenario of Competing Processes with a Critical Point \& Natural Repair Mechanisms}

Radiolysis of water can be viewed as a scenario of competing processes, water decomposition and reformation, in which the outcome will depend upon where the processes reach a balance or equilibrium. Decomposition will still occur even in the presence of additives but they serve to alter the net outcome by affecting the chemical reactions such that one process becomes more dominat. This was seen somewhat in Figure 2 and is shown more explicitly in Figure 3[26] which shows that the equilibrium point or threshold for which beyond negative effects manifest can be increased through bolstering the scavenging capacity and altering the balance such that the favorable processes are dominant.

In a biological system, it appears to be a similar scenario between biochemical damage and repair processes. Free radicals and ROS were identified as the root cause of oxidative stress and while their production is attributed to exposure to external sources like $\mathrm{X}$-rays, ozone, cigarette smoke, air pollutants and industrial chemicals [27], they are also generated naturally during a variety of energy-generating biochemical reactions and cellular functions [5]. In fact, the ROS actually serve a necessary 


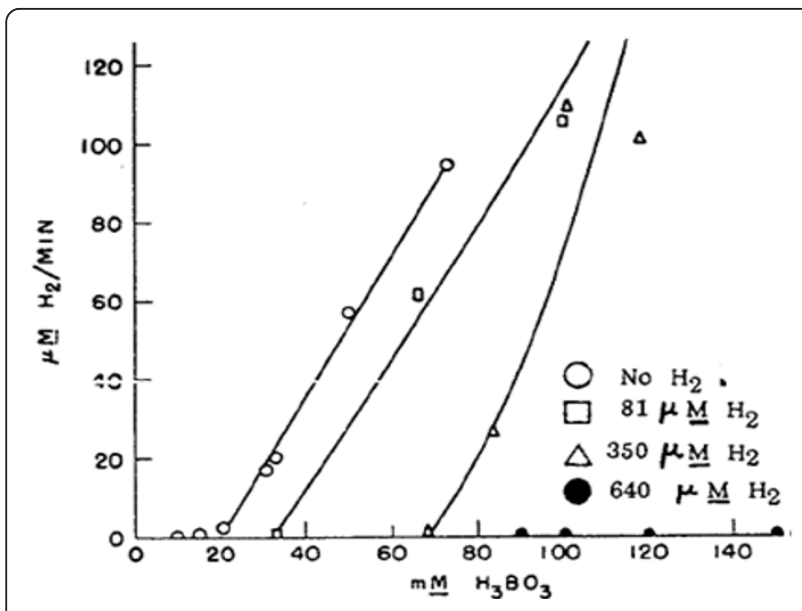

Figure 3 Relative contribution of the water decomposition process is associated with boric acid concentration measured in milli-molar on the abscissa. System scavenging capacity or relative contribution of the water reformation process is associated with the initial amount of dissolved $\mathrm{H}_{2}$ measured in micro-molar concentrations (each curve). Manifestation of negative systematic effects is reflected by the amount of water decomposition from radiolysis as reflected by $\mathrm{H}_{2}$ gas generation rates measured in micro-molar concentrations per minute on the ordinate. Figure illustrates that the addition of dissolved $\mathrm{H}_{2}$ increases the scavenging capacity of the water therefore increasing the threshold and delaying the onset of when decomposition becomes the dominant process [26].

function as signaling molecules that critically modulate the activation of the immune system and thus participate in antibacterial defense [28]. Thus, neutralization of all free radicals would not be desirable. Oxidative stress occurs when there is an imbalance between antioxidants and ROS and free radicals [29] such as when ROS concentrations increase due to radiation exposure generating them by ionization. Chopping [3] observes, "The cell is protected by different DNA repair mechanisms which try to restore the damage. We don't know the details, except when the repair goes wrong (e.g. a replacement of a lost nucleotide by a "wrong" base pair, etc.)... The cell contains natural radical scavengers. As long as they are in excess of the radiolysis products, the DNA may be protected. When the products exceed the amount of scavengers, radiation damage and cancer induction may occur. In principle, there could thus be a threshold dose for radiation damage, at which the free radicals formed exceed the capacity of scavenging. The scavenging capacity may differ from individual to individual depending on his/her physical condition." Experimental investigations regarding long-duration space flights in particular clearly showed increased oxidative stress markers and a reduction in antioxidants after these flights [30,7]. Kennedy et al. [31] demonstrated that exposure to space radiation may compromise the capacity of the host antioxidant defense system and that this adverse biological effect can be prevented, at least partially, by dietary supplementation with agents expected to have effects on antioxidant activities. Interestingly and similarly so, the radiation resistance of the bacteria Deinococcus radiodurans that can grow under chronic $\gamma$ radiation (50 Gy/ hr) or recover from acute doses greater than $10 \mathrm{kGy}$ has been attributed to the role of antioxidants in mitigating the extent of oxidative damage [32-34]. Thus there appear to be similarities between the nuclear and biological systems in how use of scavengers can enhance and bolster the favorable process thereby increasing the natural radiation resistance of the system. Chopping [3] points out that several radiation protection agents are known and probably function as scavengers for the products of water radiolysis. However, the oxygen effect to promote ROS production isn't seen for the higher LET $\alpha$ radiation where the OER is 1 , as opposed to 3 as for the case of X-rays, implying that direct damage such as double strand DNA breaks becomes the more dominant type of damage process for higher LET radiation. Therefore, for the high LET space radiation, scavenging alone may not be an effective mitigation approach. Thus, we envision a strategy that interrupts the chain of events leading to biological disease during the chemical and biological stages. In particular, we propose a strategy that (1) bolsters antioxidant capacity (2) supports natural repair processes and (3) manages biological response to radiation insult. This approach could have a great effect for increasing the threshold tolerance for radiation damage before it propagates into systematic symptoms, disease and ailments.

\section{Radiation protection by a conjunctive bio-chemical approach}

Over the course of the last century, a wealth of knowledge has been accumulated on the effect of radiation on biological systems. Areas spanning in scope from DNA damage up to changes in physiology have received extensive study. To date, biology studies of radiation damage have largely focused on components of DNA repair systems such ataxia telangiectasia mutated gene (ATM). More recently, however, it has been found that modification of key molecular targets can protect tissue from radiation induced fibrosis in mice exposed to doses up to 25 Gy $[35,36]$. It has also been found that changes in APOE (Apolipoprotein E) genotype dramatically influences survival following Total Body Irradiation (TBI) in murine models. These results imply that modification of key molecular targets to induce biological changes in the host can protect tissue from radiation damage. Turner [24] notes that, "for carcinogensis or 
transformation, for example, such biological promoters (radioprotectors) can dwarf the effects of physical factors, such as LET and dose rate, on dose-response relationships."

Radioprotectors have been implicated to work by the following chemical and biological protective mechanisms:

1. radical scavenging of toxic decomposition products of free radicals and ROS

2. repair of biological molecules by donation of $\mathrm{H}$ atoms since hydrogen bonds are among the weakest in biological molecules and such are the first to be broken [37]

3. interaction with cellular components (binding, altering metabolic pathway, etc.)

Interaction with cellular components can have biological effects that lend to radioprotection like hypoxia, alteration of metabolic state, and anti-apoptotic and anti-inflammatory properties. Tissue hypoxia decreases the radiosensitivity of cells by minimizing the $\mathrm{O}_{2}$ effect and can be produced chemically by impairing oxygen transport (binding up hemogloblin with another molecule) or biologically by either restricting blood flow (vasoconstrictor drug, hypocapnia, etc.) or lowering blood pressure (vasodilator drug). Vasodilation along with other circulatory enhancements may also enhance the natural repair mechanism as it is believed to be more effective in a living organism, where the cells are in continuous exchange with the surrounding cells and body fluids, than in the tissue samples often studied in the laboratory [3]. Inducing a hypometabolic state which resembles hibernation, may contribute to tolerance against oxidative stress. Metabolic rates in hibernating marmots and ground squirrels help delay the onset of obvious damage. Also, survival times for guinea pigs that have received massive doses of radiation (> 6000 rads) have been extended from several hours to about 4 days through the use of central nervous system depressants (pentobarbital) where it has been attributed to partial protection from central nervous system syndrome [37]. Furthermore, a hypometabolic status may also prove to be an ideal therapy for various shock or trauma states in which dramatic reduction in metabolic demands may be highly protective [38]. Anti-apoptotic properties can mitigate organ damage such as in IR injury by reducing the amount of cellular self destruction. Interference with mitosis and DNA synthesis may slow cells in their radio-resistant phase of cell division or afford more time for natural repair of the cell prior to replication of the damage.
We hypothesize that therapeutic medical gases can serve as radioprotectors and biological signaling molecules to work conjunctively in preventing, protecting, and repairing radiation damage

Medical gases might prove to have lower chemical toxicity and thereby permit increased dose administration. If so, this could improve effectiveness as many of the radiation protective agents are limited to being administered in small doses due to their chemical toxicity [3]. Furthermore, incorporating the biological aspect with the chemical aspect of scavenging radiolysis byproducts may prove to be particularly effective for space radiation than using low LET radioprotectors as direct damage such as DNA double strand breaks likely become the more dominant damage mechanisms for the higher LET radiation [3]. $\mathrm{NO}, \mathrm{CO}, \mathrm{H}_{2} \mathrm{~S}$ and $\mathrm{H}_{2}$ are gaseous signaling molecules in humans. These molecules act as transmitters of information between cells by chemically interacting with cell receptors to trigger a response within the cell. These comprise some of the medical gases of interest and many of them act both on the chemical level in the form of antioxidant radical scavenging and on the biological level in the form anti-inflammatory, antiapoptotic, and other biological effects. Extensive and more detailed information about these gases in a therapeutic role can be found in reference [23] which provides a detailed description of medical gases of interest and their properties and [39] provides detailed information pertaining in particular to $\mathrm{H}_{2}$.

\section{Hydrogen \\ We hypothesize that hydrogen can repair biological radicals by $\mathrm{H}$ atom donation and/or supplement antioxidant capacity either directly as an antioxidant or indirectly as a signaling molecule to trigger production of natural antioxidant enzymes}

Hydrogen properties as a medical gas are summarized in Table 1 . Hydrogen may have potential as a safe and potent therapeutic medical gas, as well as several potential advantages over current pharmacological therapies for the following reasons:

- It is highly diffusible and as such may potentially reach subcellular compartments, such as mitochondria and nuclei, which are the primary site of ROS generation and DNA damage [40] and are also notoriously difficult to target pharmacologically.

- Its hyporeactivity with other gases at therapeutic concentrations may allow hydrogen to be administered with other therapeutic gases, including inhaled anaesthesia agents [41].

- $\mathrm{H}_{2}$ may spare the innate immune system while still allowing phagocytosis of infecting organisms. When 
Table 1 Cited Properties of $\mathrm{H}_{2}$ as a Medical Gas with Suggested Chemical/Biological Mechanisms.

\begin{tabular}{|c|c|}
\hline $\begin{array}{l}\text { Biochemical } \\
\text { Mechanism }\end{array}$ & Notes \\
\hline \multirow[t]{5}{*}{$\begin{array}{l}\text { radical scavenging } \\
\text { antioxidant }\end{array}$} & $\begin{array}{l}\text { - selectively reduces hydroxyl radicals }(\cdot \mathrm{OH}) \text { and reactive nitrogen oxide species }\left(\mathrm{NO}_{2} \text { and } \mathrm{N}_{2} \mathrm{O}_{3}\right) \text { but did not eliminate } \mathrm{O}_{2}^{-} \\
\text {or } \mathrm{H}_{2} \mathrm{O}_{2} \text { when tested in in vitro [40]. }\end{array}$ \\
\hline & $\begin{array}{c}\text { - does not decrease the steady-state levels of nitric oxide (NO) [40] which may be beneficial as endogenous NO signaling } \\
\text { pathways modulate pulmonary vascular tone and leukocyte/endothelial interactions [64]. }\end{array}$ \\
\hline & • increases antioxidant enzymes such as catalase, superoxide dismutase or heme oxygenase-1 $[39,44]$. \\
\hline & • diminished lipid peroxidation as indicated by MDA levels when compared to air-treated grafts [65]. \\
\hline & $\begin{array}{c}\text { - drinking hydrogen-containing water with concentrations as low as } 0.04 \mathrm{mM} \text {, significantly reduced the loss of } \\
\text { dopaminergic neurons, decreased accumulation of DNA damage, and lipid peroxidation in mice with Parkinson's disease } \\
\text { induced by oral administration of MPTP [66]. }\end{array}$ \\
\hline anti-apoptotic & $\cdot$ postulated to inhibit caspase-3 activation [67]. \\
\hline anti-inflammatory & $\begin{array}{l}\text { - down-regulation of pro-inflammatory cytokines, such as interleukin (IL)-1 } \beta \text {, IL-6, chemokine (CC motif) ligand } 2 \text { and } \\
\text { tumor necrosis factor- } \alpha \text { (TNF- } \alpha)[68,69] .\end{array}$ \\
\hline
\end{tabular}

tested in vitro, it did not eliminate $\mathrm{O}_{2}{ }^{-}$or $\mathrm{H}_{2} \mathrm{O}_{2}$ which have important functions in neutrophils and macrophages as they must generate ROS in order to kill some types of bacteria engulfed by phagocytosis [40]. It is not clear whether a similar reaction preferentially occurs under complex biological conditions. Experimental studies have demonstrated that hydrogen has potent therapeutic efficacies on both parasite infection [42] and polymicrobial sepsis [43].

- No adverse effects have been found in humans drinking hydrogen water in a study that examined the effects of drinking hydrogen-rich water (HW) for radiation-induced late adverse effects $[44,45]$. Studies showed that the consumption of HW for 6 months resulted in significant decrease of serum levels of derivatives of Reactive Oxidative Metabolites (dROMs) and an increase of biological antioxidant power determined by Free Radical Analytical System (FRAS). No severe adverse effects were seen during follow up period. These results suggest that drinking HW improved Quality of Life (QOL), associated with decrease of oxidative injury markers, in patients with radiotherapy.

Hydrogen has only recently been considered for therapeutic applications for radiation exposure $[46,47]$ and recent results are beginning to preliminarily demonstrate its radioprotective effects in cultured cells and rats when exposed to 4-8 Gy of $\gamma$-irradiation from a Co60 source [48]. Qian, et al [48] found that a hydrogen rich PBS treatment applied to human lymphocyte AHH1 cells increased cell vitality in that it decreased cellular lactate dehydrogenase (LDH) leakage and attenuated apoptosis. When the treatment was applied in vivo to male BALB/c rats, they found it attenuated intestinal injury, helped sustain levels of natural antioxidant enzymes GSH \& SOD, and reduced both lipid peroxidation (as indicated by MDA) and oxidative stress (as indicated by DNA base damage/lesion 8-OHdG). The protective effects appear to be concentration dependent, at least within the range of their test (up to $0.4 \mathrm{mmol} /$ $\mathrm{L}$ ), and are more effective as a pre-treatment before exposure rather than after. This may imply a protective mechanism from an antioxidant role either by the hydrogen itself or by it 'signaling' the production of natural anti-oxidant enzymes. While there appears to be insignificant differences in levels of natural antioxidant enzymes GSH \& SOD from the treatment in this experiment, other experiments have indicated hydrogen treatment appears to increase antioxidant enzymes such as catalase, SOD or heme oxygenase-1 $[39,44]$. None the less, a protective effect seems apparent and questions of how much hydrogen can be absorbed by ingestion, inhalation or injection and how long it will remain effective along with other questions remain to be addressed.

\section{Nitric Oxide}

We hypothesize that NO and thrombospondin-1 signaling

might be used conjunctively to manage response to radiation insult for tissue preservation

Medical properties for NO are summarized in Table 2 and effects are shown in Figure 4[49]. NO regulates platelet activity, preservation of the normal structure of the vessel wall and causes blood vessel dilation which may increase tissue blood supply [23]. This could abate inflammatory response and thus protect tissue from oxidative injury. Results from NO studies that have examined the ability of patients to inhale NO to improve outcome of acute respiratory distress syndrome (ARDS) have had discrepant results from positive, negative or neutral outcomes. Thus NO may be linked with both protective and toxic effects depending upon concentrations, source, timing of administration and the environment suggesting a narrow window for administration in the treatment of oxidative injuries [50]. Reduction of excessive and deleterious NO effects appear to be 
Table 2 Cited Properties of NO as a Medical Gas with Suggested Chemical/Biological Mechanisms.

\begin{tabular}{|c|c|}
\hline $\begin{array}{l}\text { Biochemical } \\
\text { Mechanism }\end{array}$ & Notes \\
\hline \multirow[t]{3}{*}{$\begin{array}{l}\text { radical scavenging } \\
\text { antioxidant }\end{array}$} & $\begin{array}{l}\text { - NO reacts with peroxy and oxy radicals generated during the process of lipid peroxidation. The reactions between NO } \\
\text { and these ROS can terminate lipid peroxidation and protect tissues from ROS-induced injuries [70]. }\end{array}$ \\
\hline & $\begin{array}{c}\text { - induces the rate-limiting antioxidant enzyme, heme oxygenase }(\mathrm{HO})-1 \text { thus imparting resistance to } \mathrm{H}_{2} \mathrm{O}_{2} \text { induced cell } \\
\text { death [71]. }\end{array}$ \\
\hline & $\begin{array}{c}\text { - in bacteria, activates the redox-sentive transcriptional regulator protein (oxyR), resulting in the subsequent expression of } \\
\text { protein protective against ROS [72]. }\end{array}$ \\
\hline anti-inflammatory & $\cdot$ inhibiting P-selectin expression and leukocyte recruitment [73]. \\
\hline $\begin{array}{l}\text { decreased } \\
\text { radiosensitivity }\end{array}$ & $\begin{array}{c}\text { - vasodilator through relaxation of vascular tone by stimulating soluble guanylate cyclase (sGC) and increased cGMP } \\
\text { content in vascular smooth muscle cells [23]. }\end{array}$ \\
\hline
\end{tabular}

controlled by blocking NO/cGMP signaling through thrombospondin-1 signaling via its receptor CD47. This has shown to both maintain the viability of normal tissues against radiation induced fibrosis in murine models following total body irradiation (25 Gy) and increase the radiosensitivity of tumors $[35,36,50]$.

\section{Carbon Monoxide}

We hypothesize that small, therapeutic concentrations of $\mathrm{CO}$ and/or when used in conjunction with other medical gases can decrease radiosensitivity without the deleterious effects of excessive $\mathrm{CO}$

Table 3 summarizes medical properties of $\mathrm{CO}$ gas. Figure 5 shows that administration of $\mathrm{H}_{2} / \mathrm{CO}$ mixtures has been shown to reduce structural damage to hearts in
Lewis rats undergoing heart transplantation (HTx) in which oxidative stress injury is caused by ischemia/ reperfusion [23] rather than radiation exposure. CO protects due to its capacity to bind hemoglobin and thereby impair oxygen transport [37] which will reduce radiosensitization caused by the $\mathrm{O}_{2}$ effect to promote radical production. However, when used solely, good protection is obtained when an animal has $2 / 3$ of its hemoglobin bind in the form of carboxyhemoglobin. At this point however, the animal is in a critical state [37] and ischemic damage, metabolic acidosis and infections are potentiated. While the adverse effects of inhaled $\mathrm{CO}$ are a major concern for clinical use, experimental models have demonstrated that potent therapeutic efficacies exist at low concentrations $[23,51]$. Soluble forms of

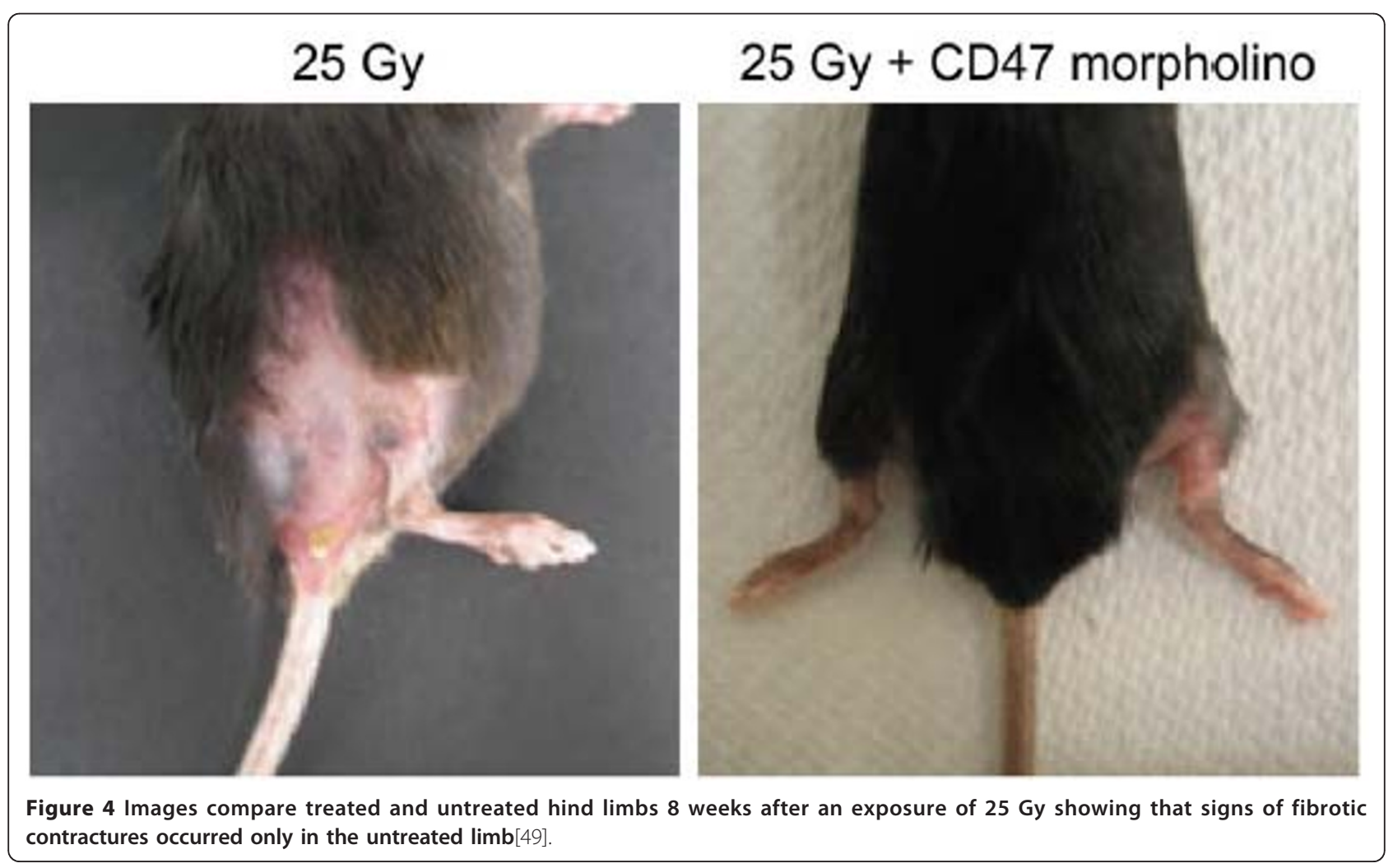


Table 3 Cited Properties of CO as a Medical Gas with Suggested Chemical/Biological Mechanisms.

\begin{tabular}{|c|c|}
\hline $\begin{array}{l}\text { Biochemical } \\
\text { Mechanism }\end{array}$ & Notes \\
\hline \multirow[t]{3}{*}{$\begin{array}{l}\text { radical scavenging } \\
\text { antioxidant }\end{array}$} & $\begin{array}{l}\text { - binds to the heme moiety of mitochondrial cytochrom c oxidase. By binding to the heme, CO may prevent degradation } \\
\text { of heme proteins which induce tissue injury by rapidly promoting peroxidation of the lipid membranes of cells }[74,75] \text {. }\end{array}$ \\
\hline & $\begin{array}{c}\text { - reduces mitochondria-derived ROS thus resulting in lower levels of ROS generation in which an adaptive cellular } \\
\text { response is triggered leading to cell survival rather than cell death [76-78]. }\end{array}$ \\
\hline & $\begin{array}{c}\text { - can induce HO-1 in cells to protect against injury [79-81]. Thus, detrimental excess of heme can be immediately } \\
\text { removed by HO-1 enzymatic activity induced by CO. }\end{array}$ \\
\hline decrease radiosensitivity & • impedes $\mathrm{O}_{2}$ transport as it binds to hemoglobin with an affinity 240 times higher than that of $\mathrm{O}_{2}$. \\
\hline
\end{tabular}

$\mathrm{CO}$, such as CO-releasing molecules, may overcome the problem of tissue hypoxia and allow clinical application $[52,53]$. Recent animal studies have shown discrepant results between exhibiting and not exhibiting antiinflammatory effects [23]. These discrepancies may be attributed to species specific differences in the affinity of $\mathrm{CO}$ for hemoglobin, or physiological differences such as respiratory rate and sensitivity to lipopolysaccharides (endotoxins) [54,55]. King and Lefer [56] point out, "When tissue is subjected to ischaemia, the lack of oxygen prevents mitochondrial respiration and oxidative phosphorlyation, which leads to a rapid decline in ATP concentration (Halestrap, 2010). Upon reperfusion, oxygen and substrates are restored to the tissue and the respiratory chain can restart, which leads to mitochondrial re-energization. This process allows mitochondria to take up $\mathrm{Ca}^{2+}$ that has accumulated during ischaemia (Halestrap, 2006). However, this restoration of oxygen also causes a surge in free radicals produced by mitochondria. The combination of oxidative stress and high matrix $\mathrm{Ca}^{2+}$ are ideal conditions for the induction of the mitochondrial permeability of transition pore (MPTP). The MPTP causes mitochondria to break down rather than synthesize ATP and, if unrestrained, can lead to cell death by way of necrosis." However, they continued in highlighting work from Elrod et al. [57] which indicates that isolated mitochondria subjected to $30 \mathrm{~min}$ of hypoxia, had a greater recovery of post-hypoxic respiration rate when treated with $\mathrm{Na}_{2} \mathrm{~S}$. As well, treating at reperfusion afforded a reduction in mitochondrial swelling and an increase in matrix density suggesting preservation of mitochondrial function [56]. This may suggest that $\mathrm{CO}$ treatment may be enhanced when used in conjunction with $\mathrm{H}_{2} \mathrm{~S}$ or some sort of MPTP inhibitor like ciclosporin A [56] in which King and Lefer referenced a study by Shanmuganathan et al 2005.
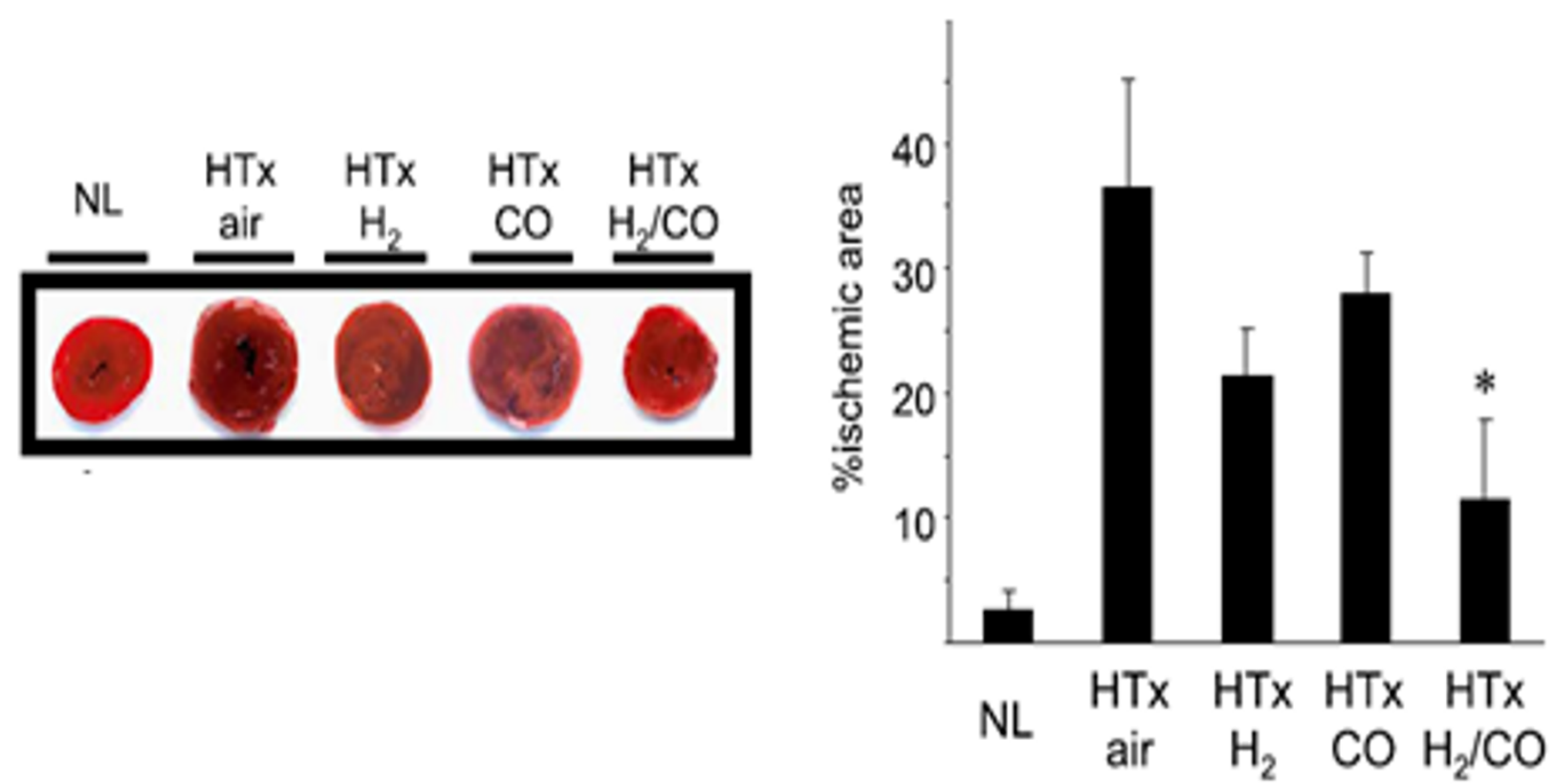

Figure 5 Extent of gross structural damage to heart graft was evaluated by $\mathrm{TTC}$ staining $3 \mathrm{hr}$ after reperfusion. $\mathrm{H}_{2}$ and $\mathrm{CO}$ inhalation reduced ischemic area following heart grafts but with only slight significance. Significant reduction is seen by dual treatment [23]. 


\section{Hydrogen Sulfide}

We hypothesize that $\mathrm{H}_{2} \mathrm{~S}$ administered in small, therapeutic concentrations can enhance antioxidant activity and aid in tissue preservation. Furthermore, it may support natural DNA repair mechanisms by temporarily slowing cell cycle progression so that more time is afforded to operate before detrimental errors are copied

The medical properties of $\mathrm{H}_{2} \mathrm{~S}$ are summarized in Table 4. $\mathrm{H}_{2} \mathrm{~S}$ exerts a wide range of physiological roles in mammalian tissue that contribute to cellular homeostasis and protect the cell against oxidative stress, apoptosis, and necrosis [56]. It is produced enzymatically at micromolar levels in mammals and is believed to help regulate body temperature and metabolic activity at physiological concentrations $[58,59]$. It has been implicated as the mechanism by which consumption of garlic attenuated cardiovascular disease where production of the gas has been demonstrated to occur by bioconversion of garlic-derived polysulfides by red blood cells [59].

\section{Possible administration methods}

Hydrogen or combinations of other medical gases could be administered to astronauts by inhalation, ingestion or injection. Inhalation could be achieved though a ventilator circuit, facemask, nasal cannula, or creating a spacesuit or spacecraft atmosphere which is composed of or contains a non-flammable gas mixture of these therapeutic medical gases. The use of Hydreliox, an exotic breathing gas mixture of $49 \%$ hydrogen, $50 \%$ helium and $1 \%$ oxygen for prevention of decompression sickness and nitrogen narcosis during very deep technical diving [60], is one example of human inhalation of hydrogen gas mixtures even though this particular mixture is suited only for deep technical diving applications. Drinking hydrogen-rich water (HW) appears to have comparable effects to hydrogen inhalation [61]. Although inhaled hydrogen gas may act more rapidly, oral intake of hydrogen-rich water is another method which may be more practical for daily life or suitable for continuous consumption in preventive or therapeutic uses. Ingestion of gas dissolved solutions may prove to be more portable, easily administered, and a safe means of delivering molecular hydrogen [62]. Gas rich water in which the gases have been dissolved could be prepared by bubbling gases into solution under pressure or other dissolution methods like swept gas diffusion. However, consideration will have to be given to loss of gas over time by dissolution and diffusion. Alternatively, some therapeutic gases such as hydrogen could be generated in solution by chemical reaction with the solution such as magnesium $\left(\mathrm{Mg}+2 \mathrm{H}_{2} \mathrm{O} \cdot \mathrm{Mg}(\mathrm{OH})_{2}+\mathrm{H}_{2}\right)$. In this case for example, a magnesium stick could be inserted into the water just prior to drinking. However, consideration will also have to be given to ingestion of the produced byproducts as well. Though oral administration is safe and convenient, hydrogen can be lost from solution by dissolution and diffusion and some hydrogen is lost in the stomach or intestine, making it difficult to control the concentration of hydrogen administrated. Administration of hydrogen via an injectable hydrogen-

Table 4 Cited Properties of $\mathrm{H}_{2} \mathrm{~S}$ as a Medical Gas with Suggested Chemical/Biological Mechanisms.

\begin{tabular}{|c|c|}
\hline $\begin{array}{l}\text { Biochemical } \\
\text { Mechanism }\end{array}$ & Notes \\
\hline \multirow{5}{*}{$\begin{array}{l}\text { radical scavenging } \\
\text { antioxidant }\end{array}$} & - antioxidant inhibitor of peroxynitrite-mediated processes via activation of N-methly-D-aspartate (NMDA) receptors [82]. \\
\hline & - shield cultured neurons from oxidative damage by increasing levels of glutathione [83]. \\
\hline & • induce upregulation of HO-1, anti-inflammatory and cytoprotective genes [84,85]. \\
\hline & • inhibits myeloperoxidase and destroys $\mathrm{H}_{2} \mathrm{O}_{2}$ [86]. \\
\hline & $\begin{array}{l}\text { - mediates mitochondrial preservation in post hypoxic conditions that are ideal for mitochondrial permeability transition } \\
\text { pore (MPTP) that would cause the mitochondria to break down and lead to cell death [56]. }\end{array}$ \\
\hline \multirow[t]{4}{*}{ anti-apoptotic } & - reduces IR induced apoptosis via reduction of cleaved caspase-3 and cleaved poly (ADP-ribose) polymerase (PARP) [87]. \\
\hline & $\begin{array}{r}\text { - protection of isolated mitochondria by decreasing } \mathrm{Ca}^{2+} \text { loading via vascular smooth muscle K } \mathrm{K}_{\text {ATP }} \text { channel-mediated } \\
\text { hyperpolarization }[23,38,56] \text { or inhibition of L-type } \mathrm{Ca}^{2+} \text { channels. }\end{array}$ \\
\hline & $\begin{array}{l}\text { - } \mathrm{H}_{2} \mathrm{~S} \text { activated STAT3 and Protein Kinase } \mathrm{C}(\mathrm{PKC}) \text { inhibits the pro-apoptotic factor Bad and upregulated the prosurvival } \\
\text { proteins } \mathrm{BCl}-2 \text { and } \mathrm{BCl}-\mathrm{xl} \text { by altering phosphorylation [56]. }\end{array}$ \\
\hline & $\begin{array}{l}\text { - } \mathrm{H}_{2} \mathrm{~S} \text { influences inactivation of pro-apoptotic pathways through survival pathway of extracellular-signal regulated kinase } \\
\text { (ERK1/2)/mitogen-activated protein kinase (MAPK) and phosphatidylinositol 3-kinase (PI-3-kinase) [56]. }\end{array}$ \\
\hline anti-inflammatory & • inhibit leukocyte adherence in the rat mesenteric microcirculation during vascular inflammation [38]. \\
\hline decrease radiosensitivity & - transiently and reversibly inhibiting mitochondrial respiration [38]. \\
\hline \multirow[t]{2}{*}{ metabolic alteration } & $\begin{array}{c}\text { - produces a "suspended animation-like" metabolic status with hypothermia and reduced oxygen demand in pigs (who } \\
\text { received it intravenously) [88]. and mice (who received hydrogen sulfide via inhalation) }[89,90] .\end{array}$ \\
\hline & $\begin{array}{l}\text { - mice breathing } 80 \text { ppm of } \mathrm{H}_{2} \mathrm{~S} \text { for } 6 \text { hr reduced heart rate, core body temperature, respiratory rate and physical activity } \\
\text { where as blood pressure remained unchanged [56]. }\end{array}$ \\
\hline
\end{tabular}


rich solution may allow delivery of more accurate concentrations of hydrogen [63]. This method of administration has been demonstrated for hydrogen in rats [48].

\section{Conclusions}

We hypothesize a systems approach of using various therapeutic medical gases as chemical radioprotectors in conjunction with biological signaling molecules to disrupt the chain of events initiated by radiation exposure and interfere with pathogenesis of disease. This could have a profound positive effect as it addresses prevention, protection, and repair. This represents a novel and feasible preventative/therapeutic strategy to address radiation-induced adverse events and thus the challenge of space radiation. While more studies are warranted to apply this therapy for space travel and determine details of optimum gas mixtures and therapy administration plans, it appears that it represents a potentially novel, therapeutic, and preventative strategy that may also ameliorate symptoms for other oxidative stress related diseases as has been shown in relevant ground-based (animal) models.

\section{List of abbreviations}

8-OHdG: 8-hydroxy-2' deoxyguanosine; APOE: Apolipoprotein E; ARDS: Acute Respiratory Distress Syndrom; ATM: ataxia telangiectasia mutated gene; BWR: Boiling Water Reactor; DNA: Deoxyribonucleic acid; dROMS: derivatives of Reactive Oxidative Metabolites; FRAS: Free Radical Analytical System; GCR: Galactic Cosmic Rays; Gy: Grey; GSH: Glutathione tripeptide; HTx: Heart Transplantation; HW: Hydrogen Water; HWC: Hydrogen Water Chemistry; HZE: High Z and Energy (Z - Atomic \#); LDH: Lactate dehydrogenase; LET: Linear Energy Transfer; MDA: Malondialdehyde; MPTP: 1-mtehyl-4-phenyl1,2,3,6-tetrahydropyridine; OCP: Open Circuit Potential; OER: Oxygen Enhancement Ratio; ppb: parts per billion; ppm: parts per million; QOL Quality of Life; ROS: Reactive Oxygen Species; SEP: Solar Energetic Particles; SOD: Superoxide dismutase; TBI: Total Body Irradiation.

\section{Acknowledgements}

This work was originally published in Proceedings of Nuclear and Emerging Technologies for Space 2011, Albuquerque, NM, February 7-10, 2011, paper 3284 and is republished with permission from the American Nuclear Society. Copyright 2011 by the American Nuclear Society, La Grange Park, Illinois.

\section{Author details \\ 'National Aeronautics and Space Administration Marshall Space Flight Center, Huntsville, Alabama, USA. ${ }^{2}$ National Aeronautics and Space Administration John H Glenn Research Center, Cleveland, Ohio, USA. ${ }^{3}$ Department of Surgery, University of Pittsburgh, Pittsburgh, PA, USA. ${ }^{4}$ National Institute of Health, National Cancer Institute, Radiation Biology Branch, Bethesda, Maryland, USA.}

\section{Authors' contributions}

MS developed the concept of using Hydrogen as a radioprotectant by noting parallels between radiation chemistry of water and radiation biology and conducting the literature review in these areas and discussing with coauthors as well as the compilation of this paper. RA provided review of the concept and provided information regarding oxidative stress from space travel and advanced methods of diagnostics. AN provided review of the concept and provided information and references regarding therapeutic uses of medical gases. DW provided review of the concept and provided information regarding NO. All authors have read and approved this manuscript.

\section{Authors' information}

Any opinions expressed are those of the authors and do not necessarily reflect the views of NASA.

\section{Competing interests}

The authors declare that they have no competing interests.

Received: 12 September 2011 Accepted: 4 April 2012

Published: 4 April 2012

\section{References}

1. Ad Hoc Committee on the Solar System Radiation Environment and NASA's Vision for Space Exploration: A Workshop Space Studies Board Division on Engineering and Physical Sciences. Space Radiation Hazards and the Vision for Space Exploration Washington DC: The National Academies Press; 2006, 7-37.

2. Parker EN: Shielding Space Travelers. Scientific American 2006, 40-47.

3. Chopping G, Liljenzin J, Rydberg J: Radiation Biology and Radiation Protection. Radiochemistry and Nuclear Chemistry. 3 edition. ButterworthHeinemann; 2002, 474-513.

4. Lin C: Radiation Chemistry in Reactor Coolant. Radiochemistry in Nuclear Power Reactors Washington, DC: National Academy Press; 1996, 125-142.

5. Nakao A, Kaczorowski DJ, Sugimoto R, Billiar TR, McCurry KR: Application of heme oxygenase-1, carbon monoxide and biliverdin for the prevention of intestinal ischemia/reperfusion injury. J Clin Biochem Nutr 2008, 42:78-88.

6. Hanaoka K: Antioxidant Effects of Water Produced by Electrolysis of Sodium Chloride Solutions. Journal of Applied Electrochemistry 2001, 31:1307-1313.

7. Testard I, Ricoul M, Hoffschir F, Flury-Herard A, Dutrillaux B, Fedorenko B, Gerasimenko V, Sabatier L: Radiation-induced Chromosome Damage in Astronauts' Lymphocytes. Int I Radiat Biol 1996, 70:403-411.

8. Barr YR, Bacal K, Jones JA, Hamilton DR: Breast Cancer and Spaceflight: Risk and Management. Aviat Space Environ Med 2007, 78:A26-37.

9. Koike Y, Frey MA, Sahiar F, Dodge R, Mohler S: Effects of HZE Particle on the Nigrostriatal Dopaminergic System in a Future Mars Mission. Acta Astronaut 2005, 56:367-378.

10. Packer L, Fuchs JJ: Vitamin C in Health and Disease New York: Marcel Dekker; 1997.

11. Sohal RS, Weindurch R: Oxidative Stress, Caloric Restriction, and Aging. Science 1996, 273:59-63.

12. Tobin BW, Uchakin PN, Leeper-Woodford SK: Insulin secretion and sensitivity in space flight: diabetogenic effects. Nutrition 2002, 18:842-8.

13. Stein TP: Space Flight and Oxidative Stress. Nutrition 2002, 18:867-871.

14. Cerutti PA, Trump BF: Inflammation and oxidative stress in carcinogenesis. Cancer Cells 1991, 3:1-7.

15. Ha H, Park J, Kim YS, Endou H: Oxidative stress and chronic allograft nephropathy. Yonsei Med J 2004, 45:1049-1052.

16. Watson T, Goon PK, Lip GY: Endothelial Progenitor Cells, Endothelial Dysfunction, Inflammation, and Oxidative Stress in Hypertension. Antioxid Redox Signal 2008, 10:1079-1788.

17. Tasaka S, Amaya F, Hashimoto S, Ishizaka A: Roles of oxidants and redox signaling in the pathogenesis of acute respiratory distress syndrome. Antioxid Redox Signal 2008, 10:739-753.

18. Nunomura A, Moreira PI, Takeda A, Smith MA, Perry G: Oxidative RNA damage and neurodegeneration. Curr Med Chem 2007, 14:2968-2975.

19. Loh KP, Huang SH, De Silva R, Tan BK, Zhu YZ: Oxidative stress: apoptosis in neuronal injury. Curr Alzheimer Res 2006, 3:327-337.

20. Wei YH, Lu CY, Wei CY, Ma YS, Lee HC: Oxidative stress in human aging and mitochondrial disease consequences of defective mitochondrial respiration and impaired antioxidant enzyme system. Chin J Physiol 2001, 44:1-11.

21. Schoenfeld MP: A Review of Radiolysis Concerns for Water Shielding in Fission Surface Power Applications. In Proceedings of Space Technology and Applications International Forum 2008 (STAIF 2008). Edited by: El-Genk M. New York: AIP Conference Proceedings 969; 2008:337-347.

22. Lillard RS, Pile DL, Butt DP: The Corrosion of Materials in Water Irradiated by $800 \mathrm{MeV}$ Protons. Journal of Nuclear Materials 2000, 278:277-289.

23. Nakao A, Sugimoto R, Billiar TR, McCurry KR: Therapeutic Antioxidant Medical Gas. J Clin Biochem Nutr 2009, 44:1-13. 
24. Turner JE: Chemical and Biological Effects of Radiation. Atoms, Radiation, and Radiation Protection. 2 edition. New York: John Wiley \& Sons, Inc; 1995, 421-422.

25. Bjergbakke E, Draganic ZD, Sehested K, Draganic IG: Radiolytic Products in Waters Part I: Computer Simulation of Some Radiolytic Processes in the Laboratory. Radioehimiea Acta 1989, 48:65-71.

26. Hart EJ, McDonell WR, Gordon S: The Decomposition of Light and Heavy Water Boric Acid Solutions by Nuclear Reactor Radiations. In Proceedings of International Conference on the Peaceful Uses of Atomic Energy. Volume 7. Geneva. New York: United Nations P/839; 1955:597.

27. Dean RT: Biochemistry and Pathology of Radical-Mediated Protein Oxidation. Biochem J 1997, 324:1-18.

28. Reth M: Hydrogen peroxide as second messenger in lymphocyte activation. Nat Immunol 2002, 3:1129-1134.

29. Halliwell B, Gutteridge JM, Cross CE: Free Radicals, Antioxidants, and Human Disease: Where are we Now? J Lab Clin Med 1992, 119:598-620.

30. Hollander J, Gore M, Fiebig R, Mazzeo R, Ohishi S, Ohno H, Ji L: Spaceflight downregulates antioxidant defense systems in rat liver. Free Radic Biol Med 1998, 24:385-90.

31. Kennedy AR, Guan J, Ware JH: Countermeasures against space radiation induced Oxidative Stress in Mice. Radiat Environ Biophys 2007, 46:201-203.

32. Daly MJ, Gaidamakova EK, Matrosova VY, Vasilenko A, Zhai M, Venkateswaran A, Hess M, Omelchenko MV, Kostandarithes HM, Makarova KS, Wackett LP, Fredrickson JK, Ghosal D: Accumulation of Mn(II) in Deinococcus radiodurans Facilitates Gamma Radiation Resistance. Scienceexpress 2004.

33. Daly MJ, Gaidamakova EK, Matrosova VY, Vasilenko A, Zhai M, Leapman RD, Lai B, Ravel B, Li SW, Kemner KM, Fredrickson JK: Protein Oxidation Implicated as the Primary Determinant of Bacterial Radioresistance. PLOS Biol 2007, 5(4):0769-0779.

34. Ghosal D, Omelchenko MV, Gaidamakova EK, Matrosova W, Vasilenko A, Venkateswaran, Zhai M, Kostandarithes HM, Brim H, Makarova KS, Wackett LP, Fredrickson JK, Daly MJ: How radiation Kills Cells: Survival of Deinococcus radiodurans and Shewanella oneidenis under Oxidative Stress. FEMS Microbiology Reviews 2005.

35. Isenberg JS, Maxhimer JB, Hyodo F, Pendra ML, Ridnour LA, DeGraff WG Tsokos M, Wink DA, Roberts DD: Thrombospondin-1 and CD47 Limit Cell and Tissue Survival of Radiation Injury. Am J Pathol 2008, 173(4):1100-1112.

36. Maxhimer JB, Soto-Pantoja DR, Ridnour LA, Shih HB, DeGraff WG, Tsokos M, Wink DA, Isenberg JS, Roberts DD: Radioprotection in Normal Tissue and Delayed Tumor Growth by Blockade of CD47 Signaling. Sci Trans/ Med 2009, 1(3):3ra7.

37. Casarett AP: Modification of Radiation Injury. Radiation Biology New Jersey: Prentice-Hall, Inc; 1968, 249-262.

38. Lefer DJ: A new gaseous signaling molecule emerges: Cardioprotective role of hydrogen sulfide. Proceedings of the National Academy of Sciences 2007, 104(46):17907-17908

39. Huang C, Kawamura T, Toyoda Y, Nakao A: Recent Advances in Hydrogen Research as a Therapeutic Medical Gas. Free Radical Research 2010, 44(9):971-982.

40. Ohsawa I, Masahiro I, Takahashi K, Watanabe M, Nishimaki K, Yamagata K, Katsura K, Katayama Y, Asoh S, Ohta S: Hydrogen Acts as a Therapeutic Antioxidant by Selectively Reducing Cytotoxic Oxygen Radicals. Nat Med 2007, 13:688-694.

41. Nakao A, Kaczorowski DJ, Wang Y, Cardinal JS, Buchholz BM, Sugiomoto R, Tobita K, Lee S, Toyoda Y, Billiar TR, McCurry KR: Amelioration of rat cardiac cold ischemia/reperfusion injury with inhaled hydrogen or carbon monoxide, or both. J Heart Lung Transplant 2010, 29:544-553.

42. Gharib B, Hanna S, Abdallahi O, Lepidi H, Gardette B, De Reggi M: Antiinflammatory properties of molecular hydrogen: investigation on parasite-induced liver inflammation. C R Acad Sci 2001, 3(324):719-724.

43. Xie K, Yu Y, Pei Y, Hou L, Chen S, Xiong L, Wang G: Protective Effects of Hydrogen Gas on Murine Polymicrobial Sepsis via Reducing Oxidative Stress and HMGB1 Release. Shock 2009.

44. Kajiyama S, Hasegawa G, Asano M, Hosoda H, Fukui M, Nakamura N, Kitawaki J, Imai S, Nakano K, Ohta M, Adachi T, Obayashi H, Yoshikawa T: Supplementation of hydrogen-rich water improves lipid and glucose metabolism in patients with type 2 diabetes or impaired glucose tolerance. Nutr Res 2008, 28:137-143.
45. Nakao A, Toyoda Y, Sharma P, Evans M, Guthrie N: Effectiveness of Hydrogen Rich Water on Antioxidant Status on Subjects with Potential Metabolic Syndrome-An Open Label Pilot Study. J Clin Biochem Nutr 2010, 46:140-149.

46. Liu C, Cui J, Sun Q, Cai J: Hydrogen Therapy may be an effective and specific Novel Treatment for Acute Radiation Syndrome. Medical Hypotheses 2009.

47. Schoenfeld MP, Ansari RR, Zakrajsek JF, Billiar TR, Toyoda Y, Wink DA, Nakao A: Hydrogen therapy may reduce the risks related to radiationinduced oxidative stress in space flight. Med Hypotheses 2010.

48. Qian L, Cao F, Cui J, Huang Y, Zhou X, Liu S, Cai J: Radioprotective effect of Hydrogen in Cultured Cells and Mice. Free Radical Research 2010, 44(3):275-282.

49. Isenberg JS: Regulation of nitric oxide signaling by thrombospondin-1: implications for anti-angiogenic therapies. Nat Rev Cancer 2009, 9(3):2009.

50. Bolli R: Cardioprotective function of inducible nitric oxide synthase and role of nitric oxide in myocardial ischemia and preconditioning: an overview of a decade of research. J Mol Cell Cardiol 2001, 33:1897-1918.

51. Han W, Lijun W, Shaopeng C, Yu KN: Exogenous Carbon Monoxide Protects the Bystander Chinese Hamster Ovary Cells in Mixed Coculture System After Alpha-Particle Irradiation. Carcinogenesis 2010, 31(2):275-280.

52. Motterlini R, Mann BE, Foresti R: Therapeutic applications of carbon monoxide-releasing molecules. Expert Opin Investig Drugs 2005, 14:1305-1318.

53. Nakao A, Toyokawa H, Tsung A, Nalesnik MA, Stolz DB, Kohmoto J, Ikeda A, Tomiyama K, Harada T, Takahashi T, Yang R, Fink MP, Morita K, Choi AM, Murase $\mathrm{N}$ : Ex vivo application of carbon monoxide in university of wisconsin solution to prevent intestinal cold ischemia/reperfusion injury. Am J Transplant 2006, 6:2243-2255.

54. Redl H, Bahrami S, Schlag G, Traber DL: Clinical detection of LPS and animal models of endotoxemia. Immunobiology 1993, 187:330-345.

55. Klimisch HJ, Chevalier HJ, Harke HP, Dontenwill W: Uptake of carbon monoxide in blood of miniature pigs and other mammals. Toxicology 1975, 3:301-310.

56. King A, Lefer D: Cytoportective actions of hydrogen sulfide in ischaemiareperfusion injury. Exp Physiol 2011, 1-7, 00.00.

57. Elrod J, Calvert J, Morrison J, Doeller J, Kraus D, Tao L, Jiao X, Scalia R, Kiss L, Szabó C, Kimura H, Chow C, Lefer D: Hydrogen sulfide attenuates myocardial ischemia-reperfusion injury by preservation of mitochondrial function. Proc Natl Acad Sci USA 2007, 104:15560-15565.

58. Kamoun P: Endogenous Production of Hydrogen Sulfide in Mammals. Amino Acids 2004, 26:243-254.

59. Lowicka $\mathrm{E}$, Beltowski J: Hydrogen Sulfide $\left(\mathrm{H}_{2} \mathrm{~S}\right)$-the Third Gas of Interest for Pharmacologist. Pharmacol Rep 2007, 59:4-24.

60. Abraini JH, Gardette-Chauffour MC, Martinez E, Rostain JC, Lemaire C: Psychophysiological Reactions in Humans During an Open Sea Dive to 500 m with a Hydrogen-Helium-Oxygen mixture. J Appl Physiol 1994, 76:1113-1118.

61. Nakashima-Kamimura N, Mori T, Ohsawa I, Asoh S, Ohta S: Molecular hydrogen alleviates nephrotoxicity induced by an anti-cancer drug cisplatin without compromising anti-tumor activity in mice. Cancer Chemother Pharmacol 2009, 64:753-761.

62. Cardinal JS, Zhan J, Wang Y, Sugimoto R, Tsung A, McCurry KR, Billiar TR, Nakao A: Oral hydrogen water prevents chronic allograft nephropathy in rats. Kidney Int 2009, 77:101-109.

63. Cai J, Kang Z, Liu K, Liu W, Li R, Zhang JH, Luo X, Sun X: Neuroprotective Effects of Hydrogen Saline in Neonatal Hypoxia-ischemia Rat Model. Brain Res 2009, 1256:129-137.

64. Pinsky DJ, Naka Y, Chowdhury NC, Liao H, Oz MC, Michler RE, Kubaszewski E, Malinski T, Stern DM: The nitric oxide/cyclic GMP pathway in organ transplantation: critical role in successful lung preservation. Proc Natl Acad Sci 1994, 91:12086-12090.

65. Buchholz BM, Kaczorowski DJ, Sugimoto R, Yang R, Wang Y, Billiar TR, McCurry KR, Bauer AJ, Nakao A: Hydrogen inhalation ameliorates oxidative stress in transplantation induced 170 intestinal graft injury. Am J Transplant 2008, 8:2015-24.

66. Fujita K, Seike T, Yutsudo N, Ohno M, Yamada H, Yamaguchi H, Sakumi K, Yamakawa Y, Kido MA, Takaki A, Katafuchi T, Tanaka Y, Nakabeppu Y, Noda M: Hydrogen in drinking water reduces dopaminergic neuronal loss in the 1-methyl-4- 173 phenyl-1,2,3,6-tetrahydropyridine mouse model of Parkinson's disease. PLoS One 2009, 4(9):e7247. 
67. Sun Q, Kang Z, Cai J, Liu W, Liu Y, Zhang JH, Denoble PJ, Tao H, Sun X: Hydrogen-rich saline protects myocardium against ischemia/reperfusion injury in rats. Exp Biol Med 2009, 234:1212-1219.

68. Mao YF, Zheng XF, Cai JM, You XM, Deng XM, Zhang JH, Jiang L, Sun XJ: Hydrogen-rich saline reduces lung injury induced by intestinal ischemia/ reperfusion in rats. Biochem Biophys Res Commun 2009, 381:602-605.

69. Chen $X L$, Zhang $Q$, Zhao R, Medford RM: Superoxide, $\mathrm{H}_{2} \mathrm{O}_{2}$, and iron are required for TNF-alpha-induced $\mathrm{MCP}$-1gene expression in endothelial cells: role of Rac1 and NADPH oxidase. Am J Physiol Heart Circ Physiol 2004, 286:1001-1007

70. Padmaja S, Huie RE: The reaction of nitric oxide with organic peroxyl radicals. Biochem Biophys Res Commun 1993, 195:539-544.

71. Kim YM, Bergonia H, Lancaster JR Jr: Nitrogen oxide-induced autoprotection in isolated rat hepatocytes. FEBS Lett 1995, 374:228-232.

72. Nunoshiba T, deRojas-Walker T, Wishnok JS, Tannenbaum SR, Demple B: Activation by nitric oxide of an oxidative-stress response that defends Escherichia coli against activated macrophages. Proc Natl Acad Sci 1993, 90:9993-9997.

73. Ahluwalia A, Foster P, Scotland RS, McLean PG, Mathur A, Perretti M Moncada S, Hobbs AJ: Antiinflammatory activity of soluble guanylate cyclase: cGMP-dependent down-regulation of P-selectin expression and leukocyte recruitment. Proc Natl Acad Sci 2004, 101:1386-13891.

74. Nath KA, Balla J, Croatt AJ, Vercellotti GM: Heme protein-mediated renal injury: a protective role for 21-aminosteroids in vitro and in vivo. Kidney Int 1995, 47:592-602.

75. Kumar S, Bandyopadhyay U: Free heme toxicity and its detoxification systems in human. Toxicol Lett 2005, 157(3):175-188

76. Bilban M, Bach FH, Otterbein SL, Ifedigbo E, d'Avila JC, Esterbauer H, Chin BY, Usheva A, Robson SC, Wagner O, Otterbein LE: Carbon monoxide orchestrates a protective response through PPARgamma. Immunity 2006, 24(5):601-610.

77. Taillé C, El-Benna J, Lanone S, Boczkowski J, Motterlini R: Mitochondrial respiratory chain and $\mathrm{NAD}(\mathrm{P}) \mathrm{H}$ oxidase are targets for the antiproliferative effect of carbon monoxide in human airway smooth muscle. J Biol Chem 2005, 280:25350-25360.

78. Zuckerbraun BS, Chin BY, Bilban M, d'Avila JC, Rao J, Billiar TR, Otterbein LE: Carbon monoxide signals via inhibition of cytochrome $c$ oxidase and generation of mitochondrial reactive oxygen species. FASEB J 2007 21:1099-1106.

79. Lee BS, Heo J, Kim YM, Shim SM, Pae HO, Kim YM, Chung HT: Carbon monoxide mediates heme oxygenase 1 induction via Nrf2 activation in hepatoma cells. Biochem Biophys Res Commun 2006, 343:965-972.

80. Sawle P, Foresti R, Mann BE, Johnson TR, Green CJ, Motterlini R: Carbon monoxide-releasing molecules (CO-RMs) attenuate the inflammatory response elicited by lipopolysaccharide in RAW264.7 murine macrophages. Br J Pharmacol 2005, 145:800-810.

81. Hegazi RA, Rao KN, Mayle A, Sepulveda AR, Otterbein LE, Plevy SE: Carbon monoxide ameliorates chronic murine colitis through a heme oxygenase 1-dependent pathway. J Exp Med 2005, 202:1703-1713.

82. Whiteman M, Armstrong JS, Chu SH, Jia-Ling S, Wong BS, Cheung NS, Halliwell B, Moore PK: The Novel Neuromodulator Hydrogen Sulfide: An Endogenous Peroxynitrite 'scavenger'? J Neurochem 2004, 90:765-768.

83. Kimura $\mathrm{Y}$, Kimura $\mathrm{H}$ : Hydrogen Sulfide Protects Neurons from Oxidative Stress. FASEB J 2004, 18:1165-1167.

84. Oh GS, Pae HO, Lee BS, Kim BN, Kim JM, Kim HR, Jeon SB, Jeon WK, Chae HJ, Chung HT: Hydrogen Sulfide Inhibits Nitric Oxide Production and Nuclear Factor-kappaB via heme oxygenase-1 Expression in RAW264.7 Macrophages Stimulated 2 with Lipopolysaccharide. Free Radic Biol Med 2006, 41:106-119.

85. Qingyou Z, Junbao D, Weijin Z, Hui Y, Chaoshu T, Chunyu Z: Impact of Hydrogen Sulfide on Carbon Monoxide/Heme Oxygenase Pathway in the Pathogenesis of Hypoxic Pulmonary Hypertension. Biochem Biophys Res Commun 2004, 371:30-37.

86. Laggner H, Muellner MK, Schreier S, Sturm B, Hermann M, Exner M, Gmeiner BM, Kapiotis S: Hydrogen sulphide: a novel physiological inhibitor of LDL atherogenic modification by HOCl. Free Radic Res 2007, 41:741-747.

87. Sodha NR, Clements RT, Feng J, Liu Y, Bianchi C, Horvath EM, Szabo C, Sellke FW: The Effects of Therapeutic Sulfide on Myocardial Apoptosis in Response to Ischemia-Reperfusion injury. Eur J Cardiothorac Surg 2008, 33:906-913.
88. Simon F, Giudici R, Duy CN, Schelzig H, Oter S, Gröger M, Wachter U, Vogt J, Speit G, Szabó C, Radermacher P, Calzia E: Hemodynamic and Metabolic Effects of Hydrogen Sulfide During Porcine Ischemia/ Reperfusion Injury. Shock 2008.

89. Blackstone $\mathrm{E}$, Morrison $\mathrm{M}$, Roth $\mathrm{MB}: \mathrm{H}_{2} \mathrm{~S}$ induces a suspended animationlike state in mice. Science 2005, 308:518.

90. Blackstone $E$, Roth MB: Suspended animation-like state protects mice from lethal hypoxia. Shock 2007, 27:370-372.

doi:10.1186/2045-9912-2-8

Cite this article as: Schoenfeld et al:: A hypothesis on biological protection from space radiation through the use of new therapeutic gases as medical counter measures. Medical Gas Research 2012 2:8.

\section{Submit your next manuscript to BioMed Central and take full advantage of:}

- Convenient online submission

- Thorough peer review

- No space constraints or color figure charges

- Immediate publication on acceptance

- Inclusion in PubMed, CAS, Scopus and Google Scholar

- Research which is freely available for redistribution 